\title{
Host preferences in Late Ordovician (Sandbian) epibenthic bryozoans: example from the Zahořany Formation of Prague Basin
}

\author{
PETR KÁCHA \& RADKO ŠARIČ
}

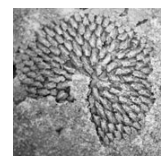

\begin{abstract}
Detailed analysis of the ecologic position of Late Ordovician epibenthic bryozoans within fossil associations from the upper part of the Zahořany Formation have revealed a statistically significant host preference. The most common hosts were found to be cephalopod shells and conulariid exoskeletons, less commonly disarticulated trilobite exoskeletons and brachiopod shells were utilized. Among the trilobite remains, the bryozoans prefered to settle on the central part of cephala in the medium-sized trilobites Dalmanitina socialis. However only one pygidium of more the 450 studied pygidia of the latter species was colonized by epibenthic bryozoans. No preferred area for attachment of bryozoans on brachiopod shells was found. The relation between fluctuating input of clastic material into the mostly siltstone sequence and the occurrence of the epibentic bryozoans is discussed. The changes in the faunal associations of the Zahorany Formation are also documented. $\bullet$ Key words: host preferences, epibiontic bryozoans, Late Ordovician, taphonomy.
\end{abstract}

KÁCHA, P. \& ŠARIČ, R. 2009. Host preferences in Late Ordovician (Sandbian) epibenthic bryozoans: example from the Zahořany Formation of Prague Basin. Bulletin of Geosciences 84(1), 169-178 (8 figures, 1 table). Czech Geological Survey, Prague. ISSN 1214-1119. Manuscript received August 20, 2007; accepted in revised form February 4, 2009; published online March 23, 2009; issued March 31, 2009.

Petr Kácha, The Institute of Rock Structure and Mechanics, Academy of Sciences of the Czech Republic, V Holešovičkách 41, 18209 Praha 8; kacha@irsm.cas.cz•Radko Šarič, Czech Geological Survey, Klárov 3, 11821 Praha 1; saric@ cgu.cz.

A re-investigation of Počaply, a locality near Beroun (upper part of the Zahořany Formation, Upper Ordovician, Sandbian) that had been briefly described by Kácha \& Šarič (1995) was undertaken in 2004-2006 (Fig. 1). We attempted to confirm the preliminarily observed changes in fossil associations upward in the sequence, and to ascertain whether the common epibiont bryozoans are only locally abundant or if they occur more widely within this formation.

Another aim of the present study was to extend and supplement the earlier observations of Kácha \& Šarič (1995), which focused on epibiont cystoporate and trepostome bryozoans attached to the exuviae of Dalmanitina proaeva (Emmrich, 1839). It is worth noting here that very few Palaeozoic bryozoans can be identified accurately from decalcified material; moreover, the entire studied sequence is siliciclastic. Thus, the exact determination of all studied bryozoans is impossible. Therefore, only approximate affiliation to the "species" of Počta (1894 and 1902) could be done.

\section{Geological setting}

The 100-120 m thick siliciclastic (mostly siltstone) sequence of the middle and upper part of the Zahořany Formation was studied in four test pits, situated $200 \mathrm{~m}$ SE from the "Na zadních borech" hill (321 m above sea level), on a woody hillside
NW from the village of Počaply (see Fig. 1). The coordinates of test pit 1 are $49^{\circ} 56^{\prime} 30.883^{\prime} \mathrm{N}, 14^{\circ} 0^{\prime} 43.488^{\prime} \mathrm{E}$; coordinates of test pits 2-4 are approximately: $49^{\circ} 56^{\prime} 28.887^{\prime} \mathrm{N}$, $14^{\circ} 0^{\prime} 41.071^{\prime} \mathrm{E}$. On average, a $1.5 \mathrm{~m}$ thick stratigraphical interval has been studied in each of these pits.

In the lower part of the studied sequence, the dark grey medium grained micaceous siltstones with variable sand admixture are generally dipping $112^{\circ} / 72^{\circ}$ (dip direction /dip). This lithology was exposed in test pit 1 , originally studied by Kácha \& Šarič (1995), revealing about $1.8 \mathrm{~m}$ thick interval only. Therefore, a new exposure, situated about $130 \mathrm{~m}$ to west, was selected for the next detailed study.

This exposure, however, is separated from the above-discussed test pit 1 by a normal fault. Therefore, correlation between these two areas was based on lithological and faunal similarities. In our opinion, the sequence exposed in pit 2 (placed in the lowermost part of the newly studied section) probably represents a stratigraphic level equivalent to pit 1 . Above these layers, approximately $30 \mathrm{~m}$ of a thick, monotonous sequence of dark-grey siltstones (generally dipping to $100^{\circ} / 54^{\circ}$ ) is exposed. In the upper part of this sequence, a $20 \mathrm{~cm}$ thick bed of quartztose sandstone was uncovered. Test pits 3 and 4 were placed above and below this sandstone bed. The content of the sand admixture, however, generally increasees toward the top of the studied sequence). 


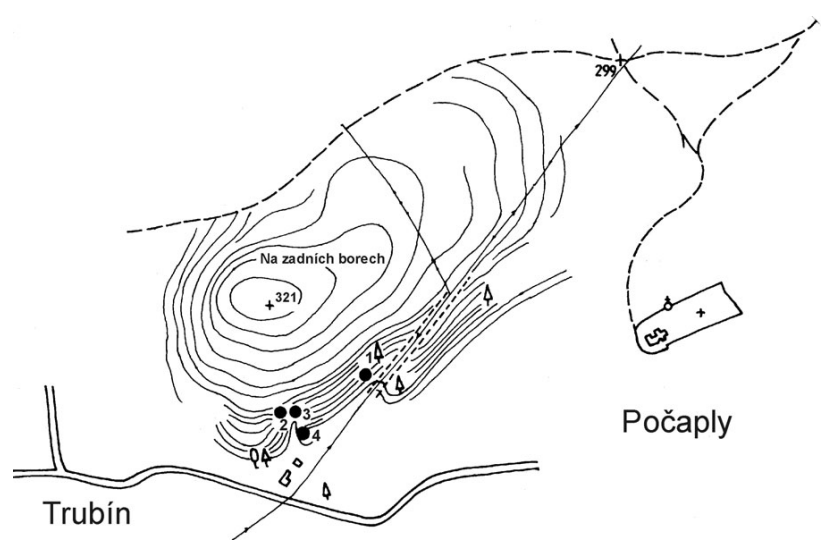

Figure 1. Geographical location of the studied outcrop and the test pits.

The section continues upwards in an estimated thickness of $70 \mathrm{~m}$ before being terminated by a basaltic ("diabase") sill at the boundary between the Zahořany and Bohdalec formations. Despite this very idealized sketch, the detailed geological situation in the studied area is much more complicated by local tectonism (see also discussion below).

Repository: Material from this study is housed in the collections of the Czech Geological Survey, collections R $\breve{S}$ (Radko Šarič) and SK (Petr Kácha), respectively.

\section{Description of the section and the fossil associations}

The platy, cross-bedded micaceous siltstones with sand admixture represents the lower part of the sequence (pits 1 and 2). The siltstones form locally carbonate-rich beds about $25 \mathrm{~cm}$ thick (Kukal 1960). Relatively highly divesified benthic association contains the following trilobites: Dalmanitina proaeva (Emmrich, 1839), Kloucekia phillipsi (Barrande, 1846), Stenopareia panderi (Barrande, 1846), Nobiliasaphus nobilis (Barrande, 1846), Eccoptochile perlata (Hawle \& Corda, 1847), Flexicalymene incerta (Barrande, 1846), Cekovia salteri (Barrande, 1852), Selenopeltis inerme inerme (Beyrich, 1846), Prionocheilus pulcher (Barrande, 1846) and Chlustinia keyserlingi (Barrande, 1846). The echinoderms are represented by Aristocystites bohemicus Barrande, 1887, Echinosphaerites infaustus Barrande, 1887, Codiacystis bohemica (Barrande, 1887) and C. moneta (Barrande, 1887). Among the brachiopods, Aegiromena sp. and Marionites sp. dominate. The bivalve Ctenodonta? sp. and the gastropod Sinuitopsis sp. are rather infrequent. The conulariid Pseudocunularia sp. and cephalopods are locally common. In these lower parts of the sequence, the epibiont cystoporate bryozoan Ceramopora vadosa Počta, 1894 often occurs attached to animal remains.

Parts of trilobite exoskeletons and the incomplete remains of other taxa show evidence of transportation and bioerosion (e.g., sponge or cyanobacterial borings identifiable as Arach-
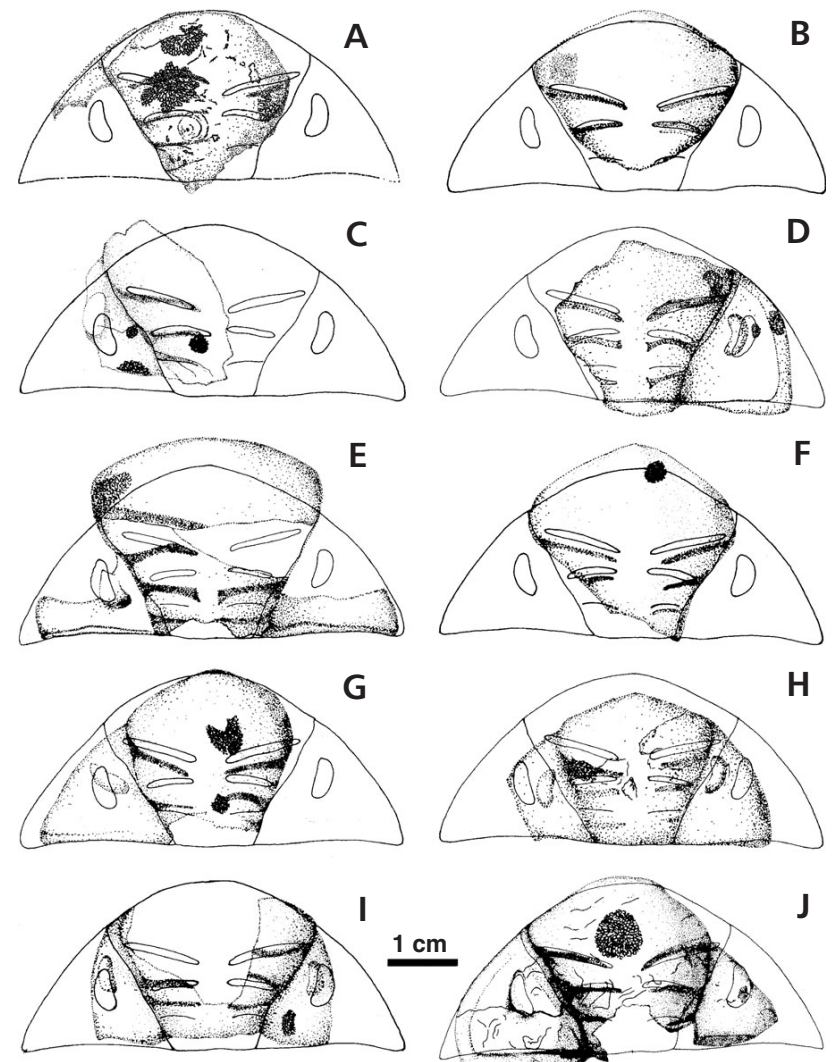

Figure 2. Schematic drawings showing the spatial distributions of cystoporate bryozoan zoaria on selected cranidia of Dalmanitina proaeva (Emm-

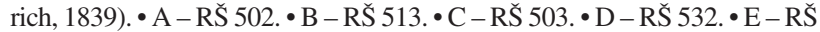
510. • F - R $\check{S} 514 . \bullet \mathrm{G}-\mathrm{RS} 511 . \bullet \mathrm{H}-\mathrm{RS} 534 . \bullet \mathrm{I}-\mathrm{R} \breve{S} 512 . \bullet \mathrm{J}-\mathrm{RS} 500$.

nostega isp., see Fig. 5K). Partially enrolled or incomplete and straight thoracopygidia of Dalmanitina proaeva (Emmrich, 1839) are relatively uncommon and are interpreted by Budil \& Bruthansová (2005) as possible transported exuviae. All of these remains are irregularly distributed within individual layers. The bioclasts locally form medium-sized $(5-10 \mathrm{~cm})$ carbonate-limonite nodules, comprising mostly crushed trilobite remains, echinoderm plates, shells of brachiopods and cephalopods (Fig. 8F). Even in these accumulations of broken organic remains, completely articulated exoskeletons of small trilobites Kloucekia phillipsi (Barrande, 1846) a Stenopareia panderi (Barrande, 1846) infrequently occur.

Internal moulds of the cystoids Aristocystites bohemicus Barrande, 1887 and Codiacystis bohemica (Barrande, 1887) occur both within beds and on aparent bedding planes. Unlike the fossils described above, their thecae show no evidence of transportation. When large numbers of cystoids occur together on apparent bedding planes, current direction can be inferred from their orientation (Fig. 8E).

In the higher parts of the sequence ( $c a 30 \mathrm{~m}$ thick siltstones between test pits No. 2 and 3), the thickness of individual beds decreases to $10 \mathrm{~cm}$ or less and the lithology also changes. In this part of the section sandy micaceous 
sandstone gives way to beds with higher clay content. In test pit 3, just below this unfossiliferous sandstone, there is a slightly different faunal association than that abovethe sandstone. Trilobites are less common and of lower diversity. Dalmanitina proaeva (Emmrich, 1839) is much rarer, but the small-sized trinucleoid Marrolithus ornatus (Sternberg, 1833) appears, as does the rare odontopleurid Primaspis tremenda (Barrande, 1852). Very common brachiopods include Rafinesquina sp., Howellites sp., Horderleyella sp. and Svobodaina sp., with frequent remains of attached trepostome bryozoans. Cystoid associations also show prominent changes. The previously very abundant Aristocystites bohemicus Barrande, 1887 and Codiacystis bohemica (Barrande, 1887) disappear, while Anomalocystites (Fig. 8C, G) appears for the first time ( $c f$. Prokop \& Petr 1999). This association is supplemented by very common, relatively large clusters of the trepostome bryozoans Monotrypa disculus (Počta, 1902) and Trematopora horrida (Počta, 1902), and disarticulated crinoid debris.

Deformed fossils occur both on the bedding planes and within individual beds. Some organic remains show traces of the bioerosion. Sorting of fossils by size and species is perceptible here, especially in siltstones rich in sand and/or clay admixtures. The thoracic segments of the narrow thoracopygons of Dalmanitina proaeva (Emmrich, 1839) are often shifted longitudinally and sagitally (Fig. 5G). Such preservation suggest multiple episodes of deformation; initially at a very early stage in unlithified sediment, then later due to pressure of overlying sedimentary strata.

The section continues with a $20 \mathrm{~cm}$ thick bed of quartz sandstone with a calcareous matrix. The quartz sandstone is overlain by a platy siltstone with a thickness of approximately $8 \mathrm{~cm}$. This part of the section was studied in detail in test pit 4 . The faunal association is comparatively rich, and its preservation is better bellow than the sandstone lower in the section. This fauna is dominated by the trinucleid trilobite Marrolithus ornatus (Sternberg, 1833). Completely articulated (including free cheeks and genal spines) and slightly disarticulated exoskeletons of Marrolithus form local accumulations on some bedding planes (Fig. 8A). Trilobites Dalmanitina proaeva (Emmrich, 1839), Stenopareia panderi (Barrande, 1846), Nobiliasaphus nobilis (Barrande, 1846), Flexicalymene incerta (Barrande, 1846), Selenopeltis inerme inerme (Beyrich, 1846), and Prionocheilus pulcher (Barrande, 1846) are less common. The large conulariid Metaconullaria sp. are very common. The cystoids Dendrocystites sedgwicki (Barrande, 1887) and Echinosphaerites infaustus, Barrande, 1887 occur also frequently. Brachiopods Aegiromena sp., Howellites sp. and Marionites sp. are rather rare in comparision with the lower part of the section (i.e. bellow sandstone). Ichnofossils Phycodes and Planolites were commonly observed. Trilobite exoskeletons and thecae of Dendrocystites are commonly oriented by current in a NNE-SSW direction (see also Mikuláš 1997).
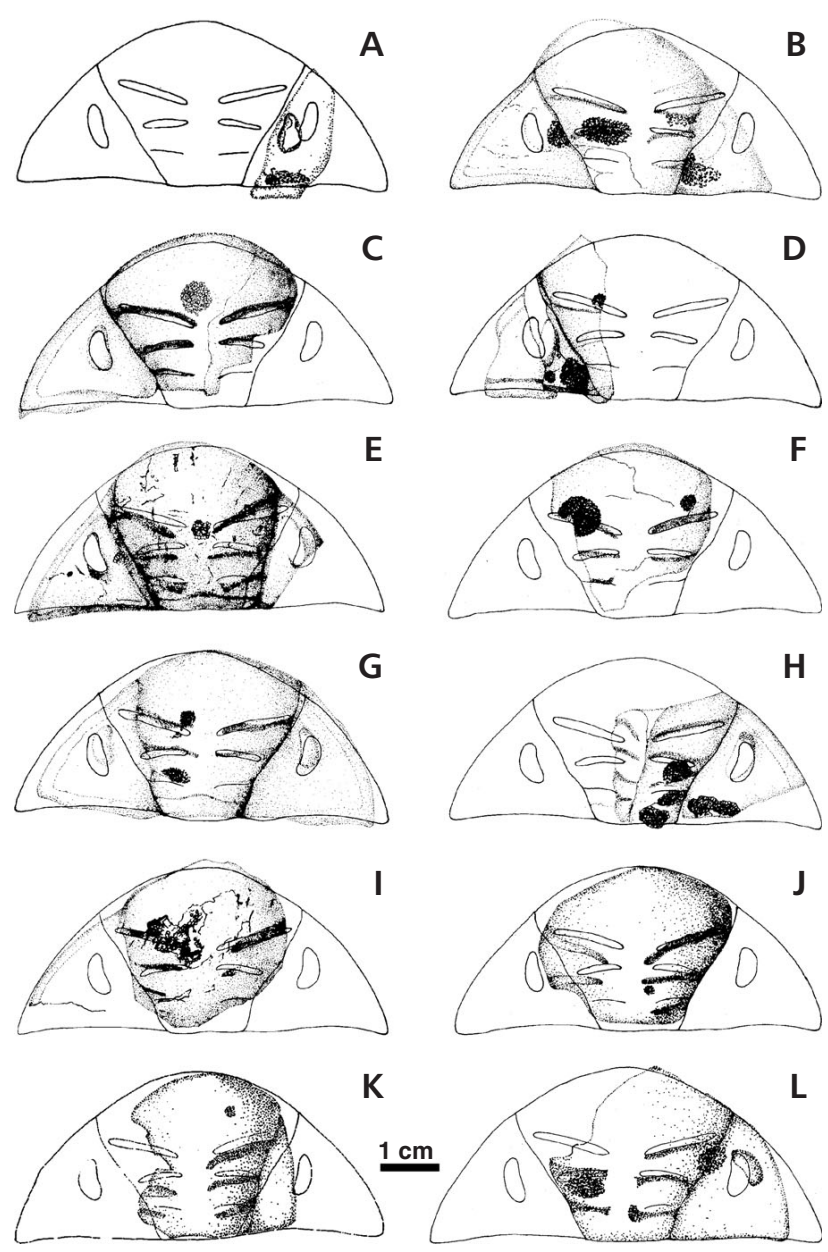

Figure 3. Schematic drawings showing the spatial distributions of cystoporate bryozoan zoaria on the selected cranidia of Dalmanitina proaeva (Emmrich, 1839). • A - R ̌ 538. • B - R ̌ 504. • C - L15075. • D - R 505.

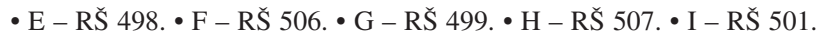
- J - R $\breve{S} 508$. $・ \mathrm{~K}-\mathrm{R} \breve{S} 509$. • L - R $\breve{S} 533$.

Absence of epibiont bryozoans in this part of the section is remarkable. The alignment of body fossils suggests that there was a bottom current present. However, the relatively common occurrence of articulated trilobites indicates a rather low flow velocity. In addition, the abundance of cystoids indicates a relatively stable oxygen level at the bottom. Consequently, the lack of epibenthic bryozoans could most probably be explained by rapid sedimentation and increasing siliciclastic influx.

\section{Description and discussion of the bryozoan epifauna}

Epibiotic cystoporates are relatively uncommon in the lower part of the studied sequence. Attached zoaria on trilobite exoskeletons, echinoderm thecae and cephalopod, brachiopod and conulariid fragments appear to show different stages of colony development. However, their preservation 

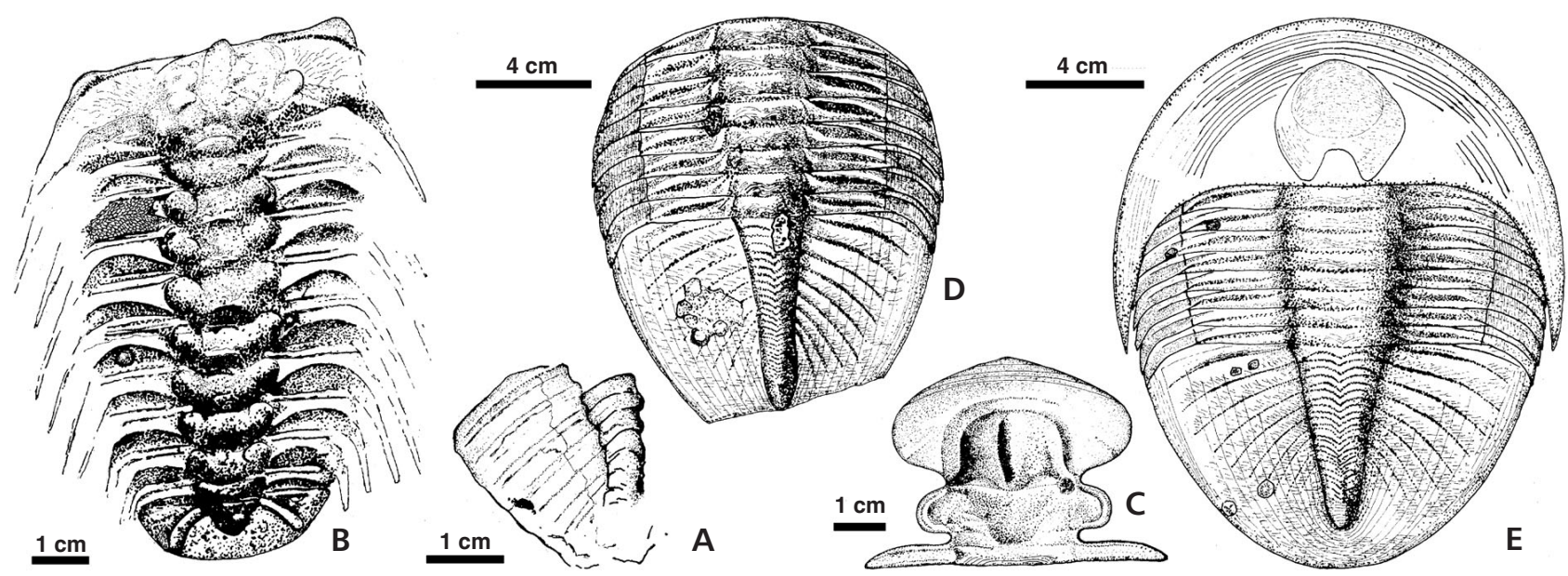

Figure 4. A-schematic drawing of the pygidium of Dalmanitina proaeva with a minute zoarium of an indeterminable bryozoan, RŠ 515 , Počaply. $\bullet$ B - schematic drawing of Selenopeltis inerme inerme (Beyrich, 1846), NM L 17271, with attached cystoporate bryozoan (see Fig. 5L). $\bullet$ C-E - schematic drawing of attached zoaria on specimens of Nobiliasaphus nobilis nobilis (Barrande, 1846), Zahořany near Beroun; C-NM L 15233, D - NM L 15297, E-NM L 15220.

is too poor for precise taxonomic determination because of decalcification and limonitisation. Genus and species level classification of bryozoans are only tentative, and are based on illustrations published by Počta (1894 and 1902).

\section{Cystoporate bryozoans attached to trilobite exoskeletons}

In the lower part of the sequence, the epibiotic bryozoan Ceramopora vadosa Počta, 1894 was found on exoskeletons of the dominant trilobite species Dalmanitina proaeva (Emmrich, 1839). However, only one minute zoarium was found (Fig. 5J) on the cranidium of Stenopareia panderi (Barrande, 1846). These findings generally support previous observation made by Kácha \& Šarič (1995).

A total of 313 trilobite cranidia and 190 pygidia were collected from test pits 1 and 2. Not more than 22 of these cranidia are encrusted by cystoporates; the total number of colonies being 43 (Table 1 and Fig. 7). The majority (30) of these colonies occupy the glabellar region. Only 6 zoaria have been found on left fixed cheeks, and 7 on right fixed cheeks. The detailed spatial distribution and the orientation of colonies on the cranidia is shown in Figs 2 and 3. The zoaria form coatings of different dimensions which, surprisingly, are not limited by the relatively deep glabellar furrows. All preserved remains probably represent young colonies whose development was abruptly interrupted, possibly by rapid deposition of sediment.
No bryozoans have been found on thoraces or isolated pleurae, which are both uncommon. Similarly, the occurrence of bryozoans on pygidia is extremely rare, being documented in only 2 of 190 pygidia found (see Table 1 and Fig. 7). In both cases, these zoaria occupy the left peripheral part of the exoskeleton (Figs 4A, 5H).

The colonies attached to both the inner and outer surfaces of the cranidia attain dimensions of 1.4 to $10 \mathrm{~mm}$. Despite the transportational and bioerosional traces visible on the trilobite exoskeletons, the bryozoans are not damaged; their preservation is often surprisingly good (however, they are secondarily decalcificated and limonitised, see above). Therefore, we suggest that colonisation occurred after transportation of the trilobite remains. It shows high energy pulses within generally rather quite water environment. The life strategy of the studied bryozoans does not correspond with that discussed by Brandt (1996), where bryozoans were found attached to the elevated parts of the exoskeleton of Flexicalymene, and were likely encrusting the living animal, even on the supposed last moulting stage.

\section{Cystoporate bryozoans attached to cephalopod shells and conulariids}

In the test pits, relatively common colonies of cystoporate bryozoan Ceramopora vadosa Počta, 1894 were found on the outer sides of "orthocone" cephalopod shells and, sur-

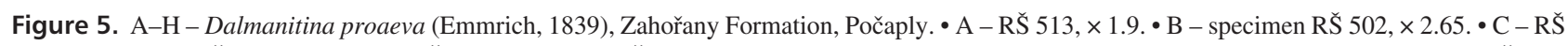
$504, \times 1.04 . \cdot \mathrm{D}-\mathrm{RS} 503, \times 2.03 . \bullet \mathrm{E}-\mathrm{RS} 500, \times 1.1 \cdot \bullet \mathrm{F}-\mathrm{R} \breve{S} 511, \times 1.5 . \bullet \mathrm{G}-$ thoracopygon with thorax partially displaced along the sag. axis, R $\breve{S} 525$, $\times 1.1 . \bullet \mathrm{H}-$ a fragment of pygidium with attached cystoporate bryozoan, RS̆ $515, \times 3.03$. $\bullet \mathrm{I}-$ attached zoaria of trepostome bryozoans on the brachiopod shells and on the crinoid stem. RS S44, $\times 1.5$. $\bullet$ J, K - Stenopareia panderi (Barrande, 1846), Zahořany Formation, Počaply. $\bullet \mathrm{J}-\mathrm{Cranidium} \mathrm{with} \mathrm{zoarium}$ of the cystoporate bryozoan RS $528, \times 2.5$. $\bullet \mathrm{K}-$ a cranidium with the traces of bioerosion, RS $528+, \times 1.3$. $\bullet \mathrm{L}-$ Selenopeltis inerme inerme $($ Beyrich, 1846), Vráž near Beroun. A cystoporate bryozoan zoarium attached on the exosceleton, L 17271, × 3.1 . 
Petr Kácha \& Radko Šarič • Host preferences in Late Ordovician (Sandbian) epibenthic bryozoans
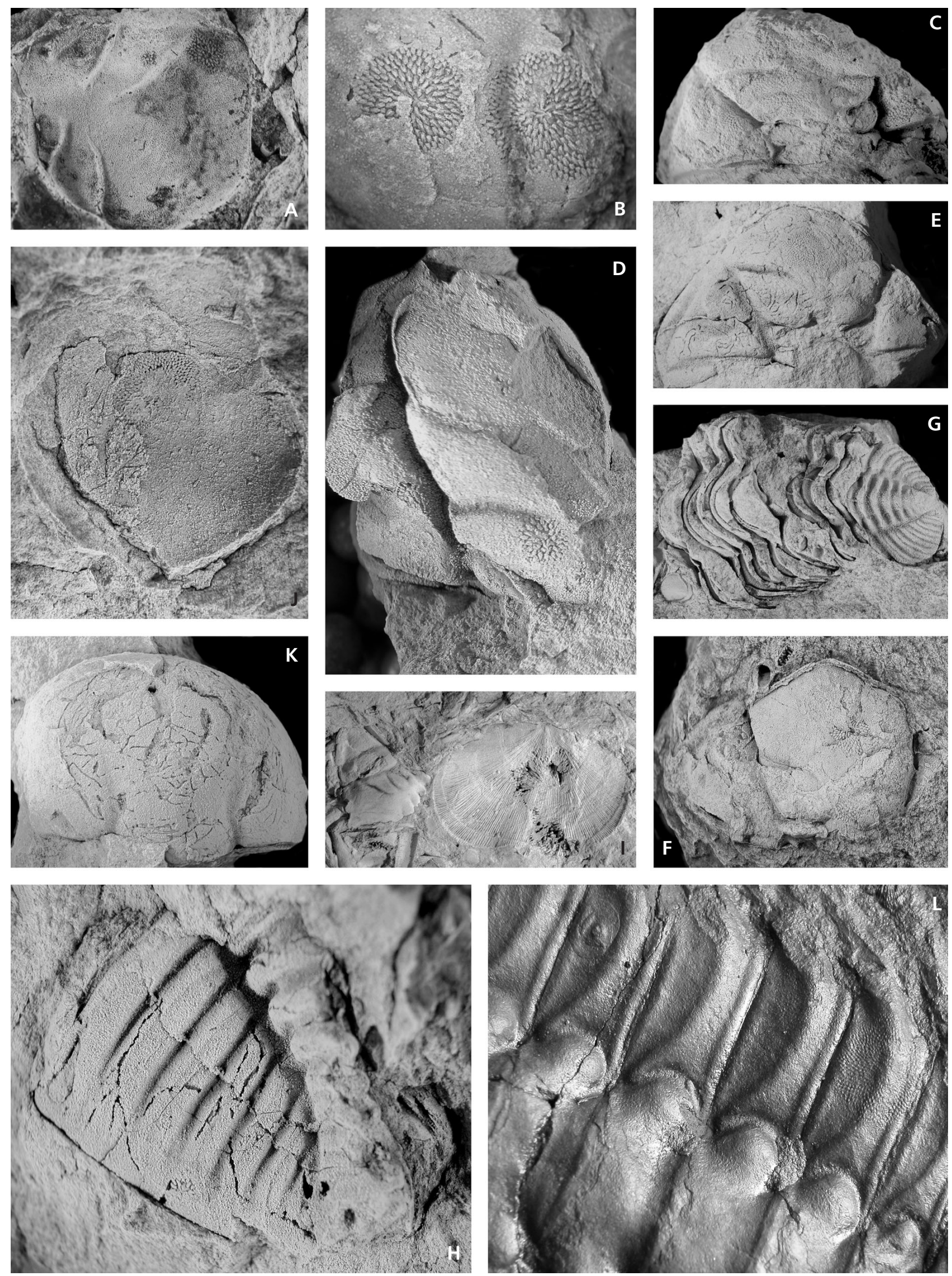
prisingly, also on conulariids. These shells are broken, incomplete, and show evidence of previous transportation and bioerosion. From a total of 82 smooth indeterminable cephalopod shells collected, 21 specimens bear attached zoaria of bryozoans. The conulariid Metaconularia? sp. is a comparatively rare element within studied faunal association, but among ten specimens found, three bear bryozoan zoaria.

We suppose that the relatively large dimensions of the cephalopod shells and conulariids enabled the attachment of a large number of bryozoan larvae and subsequent undisturbed colony growth. In this respect, the shells probably represented suitable hard substrate for bryozoan colonisation. Some of the cephalopod shells are almost completely coated by bryozoan colonies, implying that the bryozoans could grew on living, swimming nautiloids. Alternatively, it is also possible that these shells were partially buried in sediment by their apical or lower parts (Baird et al. 1989, Galle \& Parsley 2005). This interpretation seems to be supported by the frequent occurrence of cephalopod shells oriented upright on bedding surfaces (Figs 6, 8).

\section{Cystoporate bryozoans attached to cystoid thecae and gastropods shells}

In a total number of 128 thecae of Aristocystites and Codiacystis, only one specimen of Codiacystis bohemica (Barrande, 1887) had a small colony of the bryozoan Ceramopora vadosa Počta, 1894 on the apical part of an internal mould. The probable explanation is that the bryozoan larva entered a decaying theca with an open cavity .

Gastropods were very rare at this locality ( 5 specimens of Sinuitopsis sp.), but attached bryozoans were found on the inner surface of the shell (on negative counterparts) in two specimens (Fig. 6B, F, P).

\section{Trepostome bryozoans}

The occurrence of trepostome bryozoans has been documented in the higher part of the sequence only, in test pit 3 (also sporadically in test pit 4). A perceptible decrease of trilobite exoskeletal remains and cephalopod shells was observed in this stratigraphic level. Here we found relatively large zoaria of Monotrypa disculus (Počta, 1902) on ten specimens of brachiopods and two crinoid stems. Their
Table 1. Frequency of the epibiont bryozoans on the animal exoskeletons and shells, Počaply section (upper part of the Zahořany Formation). $\mathrm{T}$ - total number of specimens; $\mathrm{S}$ - specimens with attached bryozoans; $\mathrm{R}$ - relative number of specimens with attached bryozoans (in \%).

\begin{tabular}{lrrc}
\hline & $\mathrm{T}$ & \multicolumn{1}{c}{$\mathrm{S}$} & $\mathrm{R}$ \\
\hline Dalmanitina proaeva - cranidium & 629 & 30 & 4.8 \\
Dalmanitina proaeva - pygidium & 461 & 1 & 0.2 \\
Kloucekia phillipsi - cranidium & 168 & 0 & 0 \\
Kloucekia phillipsi - pygidium & 74 & 0 & 0 \\
Stenopareia panderi - cranidium & 84 & 1 & 1.2 \\
Stenopareia panderi - pygidium & 49 & 0 & 0 \\
Aristocystites bohemicus & 416 & 0 & 0 \\
Codiacystis bohemica & 258 & 1 & 0.4 \\
brachiopods & 195 & 15 & 7.7 \\
cephalopods & 321 & 203 & 63.2 \\
conularids & 53 & 31 & 58.5 \\
gastropods & 35 & 2 & 5.7 \\
\hline
\end{tabular}

attachment to these hard shells may be considered as escapist strategy for epibentic bryozoans which need a hard substrate for their growth (soft bottom probably could not offer sufficiently favourable conditions). The preservation of these colonies (Figs 5I, 6A, C, I, K, M, 8B) suggests that both the brachiopods and echinoderms were probably colonized while they were alive ( $c f$. McNamara 1978).

\section{Epibenthic bryozoans occurrence on other localities of the Zahořany Formation}

In the Barrande collections of the National Museum, Prague, the complete exoskeleton, cranidium and thoracopygon of Nobiliasaphus nobilis nobilis (Barrande, 1846) (NM L15220, L15233, and L15297 respectively) are housed. These specimens were figured by Barrande (1852, pl. 32, figs 1, 4 and pl. 35, fig. 8) and are labelled as coming from the classical locality Zahořany near Beroun. A few cystoporate bryozoan zoaria are attached the cephalon, to the wide and flat thoracic segments, and to the pygidium.

In addition, a cephalon of Dalmanitina proaeva (Emmrich, 1839) (NM L15075) from the same locality was figured by Barrande (1852, pl. 26, fig. 25). This specimen has a bryozoan colony attached to the middle part of the glabella.

Figure 6. A, C, I, K, M - the attached zoaria of trepostome bryozoans on brachiopod (Aegiromena? sp.) shells and on the crinoid stems. $\bullet$ A - RS 550 , $\times 1.8 \cdot \bullet \mathrm{C}-\mathrm{RS} 545, \times 2.5 . \cdot \mathrm{I}-\mathrm{RS} 546, \times 1.9 . \bullet \mathrm{K}-\mathrm{RS} 542, \times 2.65 . \bullet \mathrm{M}-\mathrm{RS} 561, \times 203 . \bullet \mathrm{B}, \mathrm{F}-$ gastropod shells $($ Sinuitopsis sp.) with attached zoaria of indeterminable bryozoans. $\bullet$ B - specimen RS 562, × 1.5. • F - specimen RŠ 563, × 1.4. • D, E, G, H, J, L, N, O - attached zoaria of cystoporate bryozoans

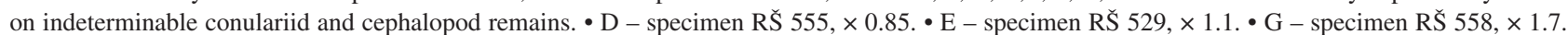

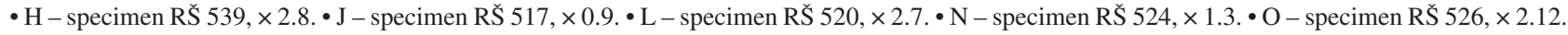
- P - Codiacystis bohemica (Barrande, 1887), an internal mould of theca with attached zoarium of the cystoporate bryozoan, RŠ $522, \times 1.7$. 
Petr Kácha \& Radko Šarič • Host preferences in Late Ordovician (Sandbian) epibenthic bryozoans
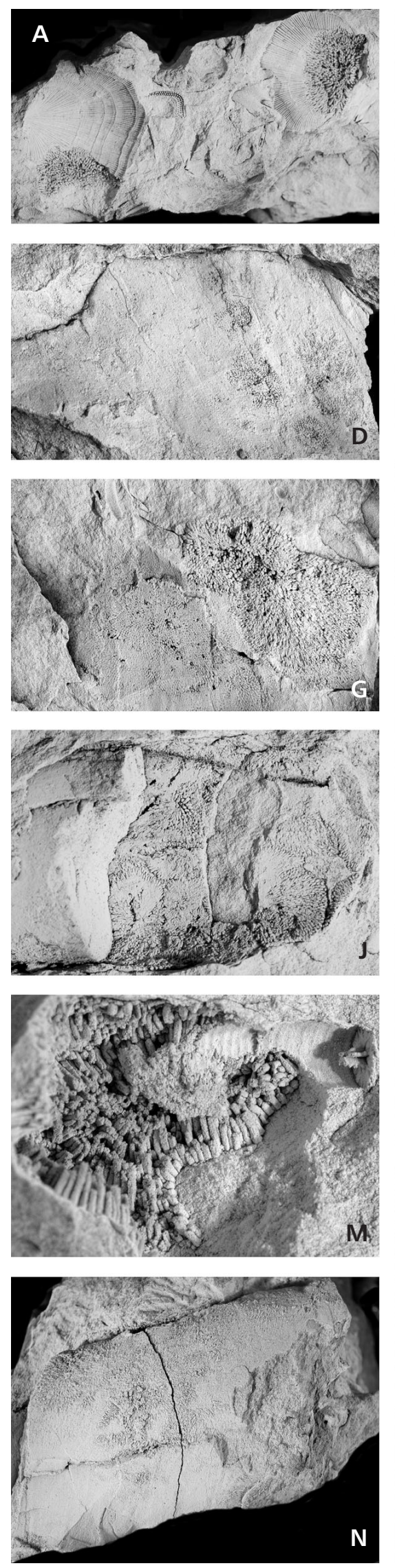
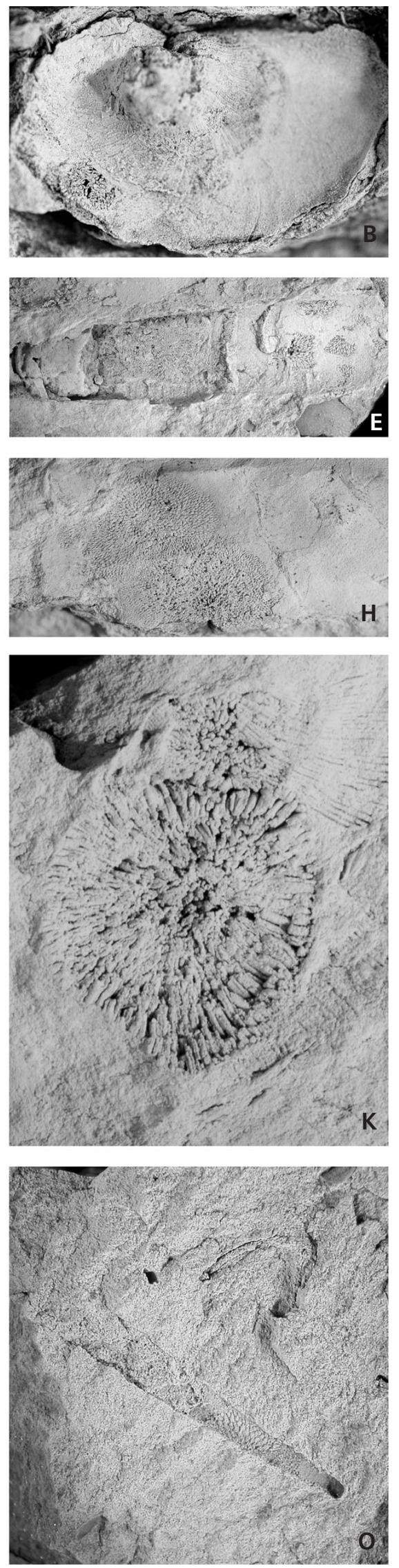
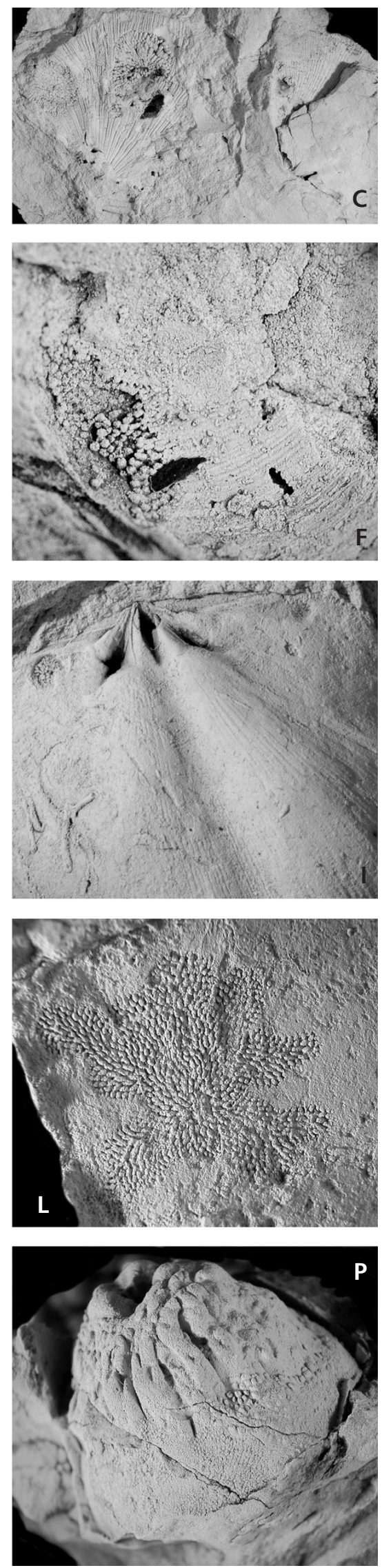
One specimen of Selenopeltis inerme inerme (Beyrich, 1846) (NM L17271), from the locality Vráž near Beroun (figured by Prantl \& Přibyl, 1949, pl. 9, fig. 2), has a cystoporate colony on the second left thoracic segment.

In all of these previously described specimens, the attached cystoporates have surprisingly not been previously discussed or figured. This is likely due to their poor preservation and relative indistinctiveness (all the specimens are re-figured herein in Figs 4 and 5). For these specimens, we infer that the attached cystoporate colonies colonised living trilobites (for discussion, see Budil \& Šarič 1995). No remains of encrusting bryozoans attached to the non-trilobite fauna have thus far been observed, with exception of the Počaply locality described herein.

\section{Host preference of Late Ordovician epibenthic bryozoans}

More than 2700 Late Ordovician fossil remains from the Počaply locality (upper part of the Zahořany Formation) were surveyed for the presence of bryozoan colonies on their exoskeletons. Such a large sample enables a quantitative analysis of host preference within this faunal association. To find hierarchical groupings within this data set, we used a cluster analysis with a single linkage algorithm. In this type of analysis, clusters are joined based on the smallest distance between the two groups. The cluster analysis revealed three well-supported clusters (Fig. 7). The first cluster consists of cephalopods and conularids, and belongs to taxa that are frequently colonized by bryozoans. More than half of the 374 studied specimens of this cluster were colonized by bryozoans. The second cluster consists of fragmentary remains (brachiopods, gastropods, and cranidia of Dalmanitina proaeva) that were colonized much less than taxa united in the first cluster (approximately 5 percent of 859 specimens were colonized). The third cluster consists of the remaining fossils that were colonized very sparsely (only 3 bryozoan colonies were found in 1510 studied specimens). We also test the statistical significance of differences in frequency of bryozoan settlement between individual taxa. The results of this test are summarized in Fig. 7, and support a topology resulting from the cluster analysis. The quantitative analysis of this large dataset clearly reveals a statistically significant host preference in colonisation of fossil remains by Late Ordovician bryozoans.

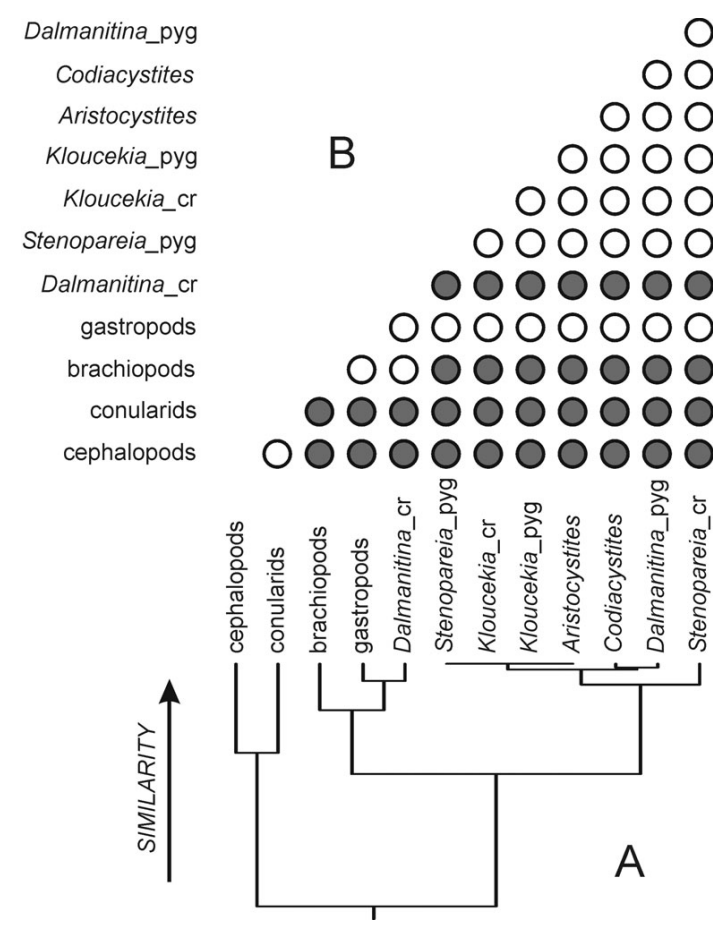

Figure 7. Diagram showing the results of cluster analysis (A) and statistical test of the differences between settlements of individual taxa (B). The cluster analysis revealed three well-supported clusters with a different frequency of bryozoan colonisation. Statistically significant differences in the level of bryozoan settlement between particular taxa are shown by gray spots.

\section{Conclusion}

The abundant occurrence of epibiont cystoporate bryozoans has been documented in the lower part of the studied section only. In all cases, the bryozoans were attached to the incomplete, apparently transported exoskeletal parts of trilobites, but were also present on cephalopod shells and conulariid exoskeletons. The first fossils (isolated clusters) of trepostome bryozoans occur about $30 \mathrm{~m}$ up in the section. Occurences of trepostome bryozoans attached to brachiopod shells and crinoid exoskeletons are comparatively rarer than in cystoporates. In the uppermost part of the section (corresponding with upper part of the Zahořany Formation), both bryozoan groups occur very frequently.

In the studied section, vertical changes in the faunal associations (e.g., Dalmanitina-dominated association replaced by Marrolithus-dominated association) have also been documented. These faunal replacements correlate

Figure 8. A - Marrolithus ornatus (Sternberg, 1833), an accumulation of incomplete but still articulated exoskeletons, SK $38, \times 1.7$. $\bullet$ B - attached zoaria of trepostome bryozoans on indeterminable brachiopod shells and on a crinoid stem, RŠ $559, \times 1.3$. $\bullet$ C - the accumulated remains of trilobite exoskeletons, brachiopod shells, crinoid remains and parts of bryozoan colonies, SK $98, \times 1.8$. $・ \mathrm{D}$ - attached zoaria of the cystoporate bryozoans on indeterminable conulariid exoskeleton, RS̆ 548, × 1.3. • E - Aristocystites bohemicus Barrande 1887, a sample of the partially oriented thecae, RS̆ $564, \times 0.7$. - F - a limonite concretion with fragmentary trilobite exoskeletons and common echionoderm and cephalopod remains, with dominant Kloucekia phillipsi (Barrande, 1846), Aristocystites bohemicus Barrande 1887, RŠ 537, × 1.3. • G - Anomalocystites sp., SK $58, \times 2.1$. 
Petr Kácha \& Radko Šarič • Host preferences in Late Ordovician (Sandbian) epibenthic bryozoans
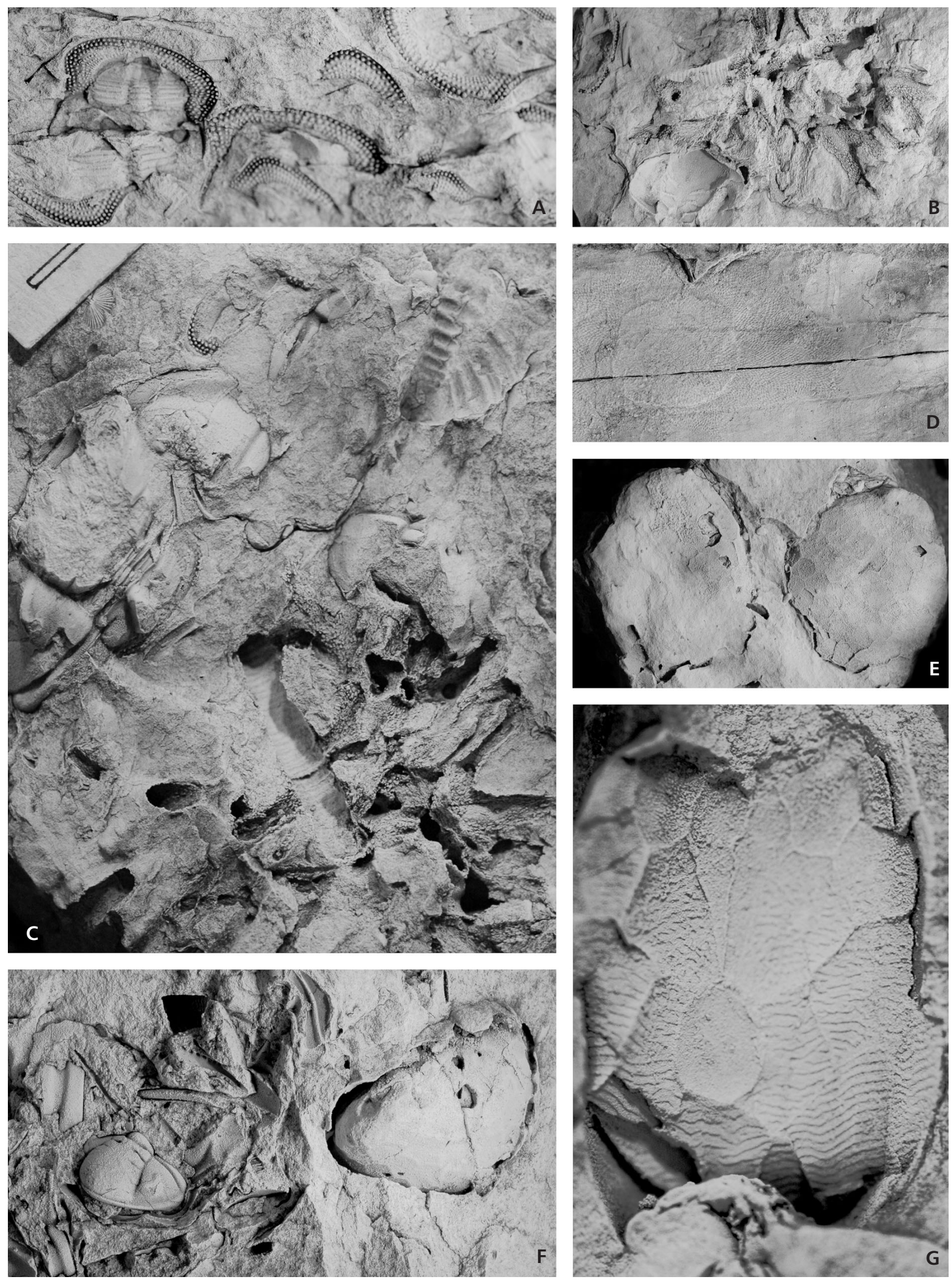
with changes in lithology reflecting probable environmental changes. These changes suggest an increase in energy (likely increased current), accompanied by an influx of sandy material higher in the section. This incursion of coarser clastics was probably also a limiting factor for the development of encrusting bryozoan colonies.

Our analysis revealed statistically significant host preference in the colonisation of fossil remains by bryozoans. The majority of cephalopod shells and conulariid exoskeletons (374 studied specimens) were colonized. The remains of all other fossils (2369 studied specimens) were colonized infrequently. To our knowledge, this is the first statictically significant host preference documented for Late Ordovician bryozoans.

\section{Acknowledgement}

We would like to express many thanks to P. Budil for valuable consultations and for help with some pictures. We also thank to J. Frýda, O. Fatka, Š. Manda, K. Zágoršek and P.D. Taylor for many useful remarks to the early version of the manuscript. The Czech Geological Survey supported this research with Investigation intent MZP0002579801.

\section{References}

BAIRD, G.C., BRETT, C.E. \& FREY, R.C. 1989. "Hitchhiking” epizoans on orthoconic cephalopods: preliminary review of the evidence and its implications. Senckenbergiana lethaea 69(5/6), 439-465.

BARRANDE, J. 1846. Notice préliminaire sur le système silurien et les trilobites de Bohême. 97 pp. C.L. Hirschfeld, Leipzig.

BARRANDE, J. 1852. Système silurien du centre de la Bohême. I ire Partie: Recherches paléontologiques. Vol. I, Crustaces: Trilobites. 935 pp., 51 pls. Prague \& Paris.

BARRANDE, J. 1887. Echinodermes. Études locales et comparatives. 356 pp., 30 pls. Ouvrage posthume de feu Joachim Barrande publié par le Doct. W. Waagen, Prague.

BRANDT, D.S. 1996. Epizoans on Flexicalymene (Trilobita) and implications for trilobite paleoecology. Journal of Paleontology 70(3), 442-449.

Budil, P. \& Bruthansová, J. 2005. Moulting in Ordovician dalmanitoid and acastoid trilobites of the Prague Basin. Preliminary observation. Geologica Acta 3(4), 373-383.

BUDIL, P. \& ŠARIČ, R. 1995. Cemented epibionts on the exoskeleton of the odontopleurid trilobite Selenopeltis vultuosa tenyl Šnajdr, 1984. Věstník Českého geologického ústavu 70(2), 29-31.

EMMrICH, H.F. 1839. De Trilobitis. Dissertatio petrefactologica quam consensu et auctoritate amplissimi philosorum ordinis. 56 pp. Nietackianis, Berolini.

GALLE, A. \& PARSLEY, R. 2005. Epibiont relationships on hyolithids demonstrated by Ordovician trepostomes (Bryozoa) and Devo- nian tabulates (Anthozoa). Bulletin of Geosciences 80(2), $125-138$.

HAWLE, I. \& CORDA, A.J.C. 1847. Prodrom einer Monographie der böhmischen Trilobiten. Abhandlungen der Königlichen Böhmischen Gesellschaft der Wissenschaften 5. 176 pp. J.G. Calve, Prague.

HORNÝ, R. \& BASTL, F. 1970. Type specimens of fossils in the National Museum, Prague. Vol. I. Trilobita. 354 pp. Museum of Natural History, Prague.

KÁCHA, P. \& ŠARIČ, R. 1995. Bryozoans attached to exuvia of the Ordovician trilobite Dalmanitina (D.) proaeva. Věstník Českého geologického ústavu 70(4), 43-46.

KLOC, G.J. 1993. Epibionts on Selenopeltinae (Odontopleurida) Trilobites, 103. Geological Society of America Abstracts with Programs 25A.

KUKAL, Z. 1960. Petrografický výzkum vrstev chlustinských barrandienského ordoviku. Sborník Státního geoogického ústavu Československé republiky, Oddíl geologický 26(1), 359-391.

KULICH, J. 1984. Trepostomatous bryozoans from the Ordovician, Silurian and Devonian of the Barrandian basin. Journal of the Czech Geological Society 29(3), 225-233.

MCNAMARA, K.J. 1978. Symbiosis between gastropods and bryozoans in the Late Ordovician of Cumbria, England. Lethaia 11, 25-40. DOI 10.1111/j.1502-3931.1978.tb01214.x

MikULÁš, R. 1997. Proudem orientované hlavové štíty trilobita Dalmanitina proaeva (Emmr.) na lokalitě Loděnice - vinice (zahořanské souvrství, ordovik Barrandienu). Zprávy o geologických výzkumech v roce 1997, 102-103.

MiKULÁš, R. 1998. Ordovician of the Barrandian area: Reconstruction of the sedimentary basin, its benthic communities and ichno assemblages. Journal of the Czech Geological Society 44(3), 147-159.

MIKULÁŠ, R. 1999. Joint occurrences of body- and trace-fossil communities (Ordovician, Barrandian area, Czech Republic). Journal of the Czech Geological Society 44, 69-78.

PoČTA, F. 1894. Système silurien du centre de la Bohême par Joachim Barrande. Ire Partie: Recherches Paleontologiques. Vol. VIII, Tome I, Bryozoaires, Hydrozoares et partie des Anthozoaires. 230 pp. Prague.

PoČTA, F. 1902. Système silurien du centre de la Bohême par Joachim Barrande. Ire Partie: Recherches Paleontologiques. Vol. VIII, Tome II, Anthozoaires et Alcyonaires. 347 pp. Prague.

PROKOP, R.J. \& PETR, V. 1999. Echinoderms in the Bohemian Ordovician. Journal of the Czech Geological Society 44, 63-68.

PRANTL, F. \& PřIBYL, A. 1949. Studie o trilobitech nadčeledi Odontopleuracea nov. superfam. Rozpravy Státního geologického ústavu Republiky československé 12, 1-221.

RICHARDS, R.P. 1972. Autecology of Richmondian brachiopods (Late Ordovician of Indiana and Ohio). Journal of Paleontology 46(3), 386-405.

TAYLOR, P.D. \& WILSON, M.A. 2003. Palaeoecology and evolution of marine hard substrate communities. Earth Science Reviews 62, 1-103. DOI 10.1016/S0012-8252(02)00131-9

TetreAulT, D.K. 1992. Paleoecologic implications of epibionts on the Silurian lichid trilobite Arctinurus, 289. Fifth North American Paleontological Convention, Abstracts and Program, Paleontological Society Special Publication 6. 